\title{
An Ethogram: A New Approach to Quantify the Severity of Diseases in Animal and Poultry
}

\author{
Motamed Elsayed Mahmoud* \\ Department of Animal Behavior and Husbandry, Egypt \\ *Corresponding author: Motamed Elsayed Mahmoud, Department of Animal Behavior and Husbandry, Sohag University, Sohag \\ Submission: 眥 September 09, 2017; Published: 些 December 07, 2017
}

\section{Editorial}

An ethogram is a behavioral picture when well customized will become an emerging in determining the severity of disease. An ethogram will exhibit the behavioral picture in digital values, instead of describing the clinical signs of healthy animal or that of diseased one in terms of displaying or disappearing certain behavioral components.

The procedure of establishing ethogram for an animal in its natural habitat or in enriched environment should be firstly performed.

Ethogram perhaps will be the cut edge for disease severity. For instance animals suffered from certain diseases exhibit various degrees of pathology. Ethogram will gather them in a coherent and digital from. So the categorizing the diseases into 3 or even 10 points will provide valuable information about the individual suffering from diseases.

Table 1: Ethogram for mice infected with a cyst forming strain of Toxoplasma gondii [1].

\begin{tabular}{|c|c|}
\hline \multicolumn{2}{|c|}{ Ethogram (10 Check Points) } \\
\hline 1 & Hunching \\
\hline 2 & Piloerection \\
\hline 3 & Warmth-seeking behavior (huddling/ burrowing bedding) \\
\hline 4 & Sunken eye \\
\hline 5 & Ptosis (dropping of upper eye lid) \\
\hline 6 & Ataxia \\
\hline 7 & Reluctant movement \\
\hline 8 & Deficient evacuation (defecation \& urination) reflexes \\
\hline 9 & Deficient touch reflexes \\
\hline 10 & LOB (lying on belly) \\
\hline
\end{tabular}

It is expected that some diseases will show the negative clinical score compared to healthy or control animals e.g. diseases associated with lowered general activity, reduced reflexes and depression. However, individual affected with certain CNS diseases may show positive clinical score.

Ethogram can cover not only clinical score, but also many objective tests that measure gait as in footprint test or using machines like veterinary gait analysis. The ethogram is also helpful in focal approaches; the context (especially social context) the sequence of behaviors, and the duration of behaviors the immediate consequences (e.g. responses of other individuals, etc.). All these displays can be translated to digital values (Table 1) [1]. The behavioral picture of ethogram seems to be extended to birds. Trinitrobenzene of sulphonic acid-induced colitis in chicken (Table 2) [2]. 
Table 2: The severity of colitis was evaluated by the customized clinical score [2].

\begin{tabular}{|c|c|c|}
\hline \multicolumn{2}{|c|}{ Clinical Score (4 Check Points) } & Value(0-4) \\
\hline \multicolumn{2}{|c|}{ Dropping consistency } & Max 4 \\
\hline 1 & Well-formed dropping & 0 \\
\hline 2 & Loose dropping & 2 \\
\hline 3 & Diarrhea & 4 \\
\hline \multicolumn{2}{|c|}{ Presence or absence of blood } & $\operatorname{Max} 4$ \\
\hline 1 & No blood & 0 \\
\hline 2 & Occult of blood & 2 \\
\hline 3 & Gross Bleeding & 4 \\
\hline
\end{tabular}

\section{Implications}

Therefore, it is important to design an ethogram for healthy, experimental control and diseased animals need for performing research studies of extensive nature.

\section{Conclusion}

The ethological approaches in experimental and clinical studies should put emphasis on to the use of ethogram.

\section{References}

1. Mahmoud ME, Nishikawa N (2016) Behavioral alterations induced by Toxoplama gondii during different stages of infection in mice. Journal of Applied Veterinary Sciences 1(1): 1-6.

2. Mahmoud ME, Hassanein K (2012) Prevention of tri-nitrobenzene of sulfonic acid- induced colitis by using extract of Aloe vera in chicken. World Veterinary Journal 5(8): 469-476. 